\section{Identifying pathological biomarkers: histochemistry still ranks high in the omics era}

\author{
C. Pellicciari, ${ }^{1}$ M. Malatesta ${ }^{2}$ \\ 'Department of Biology and \\ Biotechnology, Laboratory of Cell \\ Biology, University of Pavia; \\ 2Department of Neurological, \\ Neuropsychological, Morphological and \\ Motor Sciences, Human Anatomy and \\ Histology Section, University of Verona, \\ Italy
}

\section{Abstract}

In recent years, omic analyses have been proposed as possible approaches to diagnosis, in particular for tumours, as they should be able to provide quantitative tools to detect and measure abnormalities in gene and protein expression, through the evaluation of transcription and translation products in the abnormal $v s$ normal tissues. Unfortunately, this approach proved to be much less powerful than expected, due to both intrinsic technical limits and the nature itself of the pathological tissues to be investigated, the heterogeneity deriving from polyclonality and tissue phenotype variability between patients being a major limiting factor in the search for unique omic biomarkers. Especially in the last few years, the application of refined techniques for investigating gene expression in situ has greatly increased the diagnostic/prognostic potential of histochemistry, while the progress in light microscopy technology and in the methods for imaging molecules in vivo have provided valuable tools for elucidating the molecular events and the basic mechanisms leading to a pathological condition. Histochemical techniques thus remain irreplaceable in pathologist's armamentarium, and it may be expected that even in the future histochemistry will keep a leading position among the methodological approaches for clinical pathology.

\section{Introduction}

Identification of reliable and unequivocal diagnostic and prognostic markers is the ultimate goal of pathologists. Following the pioneering intuition of Giovanni Battista Morgagni (1682-1771), who first attempted to relate changes in macroscopic anatomy to the altered physiological features characterizing diseases, pathologists aim at detecting the most appropriate biomarker(s) enabling recognition of the earliest signs of a pathological condition.

In recent years, genomics and, especially, proteomics and transcriptomics did enter the pathologist's practice, and were initially foreseen as the final approach to diagnosis, in particular for tumours. In principle, omic analyses should provide quantitative tools to detect and measure abnormalities in gene and protein expression, through the evaluation of transcription and translation products in the abnormal $v s$ normal tissues. ${ }^{1}$

Unfortunately, this approach proved to be much less powerful than expected, due to both intrinsic technical limits and the nature itself of the pathological tissues to be investigated. In fact, results from omic analyses reflect the contents in transcripts or proteins of whole cell extracts, whereas the occurrence of gene expression abnormalities in a pathological specimen may often be restricted to minor tissue fractions: this makes almost impossible to detect tiny quantitative changes in one or few aberrantly expressed molecules. The heterogeneity deriving from polyclonality and tissue phenotype variability between patients is another major limiting factor in the search for unique omic biomarkers. As a consequence, it has been suggested to use complex bioinformatic analyses to effectively mine heterogeneous quantitative data sets and extract their qualitative contents; ${ }^{1}$ a consensus, however, has not yet been reached on how to deal with omic data in the attempt to identify suitable pathological biomarker(s).

\section{The present role of histochem- istry in clinical pathology}

It is since the 1950's that histochemistry has been recognized as the discipline linking morphology (microanatomy and histology) and biochemistry, and has provided pathologists with a versatile armamentarium of methods and procedures enabling the recognition in situ of significant pathological markers. ${ }^{2,3}$

The advantage provided by the histochemical approach is the possibility to detect in situ, by microscopy techniques, changes in cell phenotype taking place even in limited portions of a pathological tissue: thus quantitative changes either in the percentage of cells positive for a given marker or in the intensity of the final reaction products within the cells allow reliable diagnostic conclusion through the comparison with the normal tissue, and well experienced pathologists often improve differential diagnosis by selecting a panel of appropriate histochemical markers.

On 12-15 October 2011, the 53 ${ }^{\text {rd }}$ Symposium
Correspondence: Prof. Carlo Pellicciari, Department of Biology and Biotechnology, Laboratory of Cell Biology, University of Pavia, via A. Ferrata 9, 27100 Pavia, Italy.

E-mail: pelli@unipv.it

Key words: histochemistry, clinical pathology

Received for publication: 27 November 2011. Accepted for publication: 6 December 2011.

This work is licensed under a Creative Commons Attribution NonCommercial 3.0 License (CC BYNC 3.0).

(C) Copyright C. Pellicciari and M. Malatesta, 2011 Licensee PAGEPress, Italy

European Journal of Histochemistry 2011; 55:e42 doi:10.4081/ejh.2011.e42

of the Society for Histochemistry has been held in Munich (Germany) with the significant subtitle Current role of Histochemistry in Preclinical and Clinical Research (http://www .helmholtz-muenchen.de/histochemistry2011/home/index.html). Also during the $34^{\text {th }}$ National Congress of the Italian Society of Histochemistry, ${ }^{4}$ more than one third of the scientific contributions concerned the application of histochemical techniques to pathological models, in humans and other Vertebrates.

This interest for the application of histochemistry in the pathological field is confirmed in the international literature: during the last two years, out of the about 25,000 articles dealing with the application of histochemical techniques published in peer-reviewed journals, more than 50\% concerned pathological (mostly tumour) subjects (source: http://www.ncbi.nlm.nih.gov/pubmed/).

Consistently, the percentage of published articles on pathological topics ranged between $25 \%$ and $40 \%$, also in the most traditional journals on histochemistry, i.e. Histochemistry and Cell Biology (http://www.springer.com/medicine/anatomie/journal/418), the Journal of Histochemistry and Cytochemistry (http:/jhc. sagepub.com/), and the European Journal of Histochemistry (www.ejh.it).

A review of the contents of the articles appeared in this latter journal showed that the majority of them were devoted to tumours.-24 As expected, immunohistochemistry has been mostly applied, and the differential expression of proteins in diseased $v s$ normal tissues has often been investigated by a multiparametric approach. ${ }^{7,11,12,14,15,22}$ A few papers were focussed on the unusual expression of proteins demonstrating possible heterogeneity within tumours classified in a single type, ${ }^{6,17}$ while proliferation, differentiation and apoptotic markers have been used to elucidate differences in the progression of malignancy and 
in the metastatic potential of tumour cells in vivo and in vitro. . $8,9,14,16,19-21,23,24^{2}$

Muscle wasting, due to physiological sarcopenia or dystrophy, has been widely considered: ${ }^{25-30}$ the simultaneous application of histochemical techniques at light and electron microscopy allowed to relate the changes in cellular phenotype with altered gene expression. Changes in the structural and functional features of the cell nucleus of myocytes and satellite cells proved to be especially suitable to detect alterations not only in the organization of muscle fibres, but also in the regeneration potential of skeletal muscle under pathological conditions and aging. ${ }^{25-28}$ Skeletal muscle has also been the subject of three interesting technical reports; ${ }^{30-32}$ and other notes on techniques have been published concerning the preparation of pathological samples to be observed in bright field or fluorescence microscopy. ${ }^{33-36}$

Histological, histochemical and morphometrical techniques have been used to investigate the effects of intoxication, infection or vaccine administration on several organs and tissues from different Vertebrate species, from fish to mammals: ${ }^{37-43}$ here too, the potential of light and electron microscopy and histochemistry has been exploited to identify minute changes in the structural organization and function of cells which heterogeneously take place in different tissues.

A growing interest is apparent for mineralized tissues, with special attention to joint alterations during development and under pathological conditions: $:^{44-49}$ in particular, articular disks have been the subject of severa papers, as the changes in their composition and organization are indicative features to understand pathological processes of internal derangement. ${ }^{45-49}$

In the wide variety of pathological conditions that have been considered in the published articles, histochemical techniques have been used not only to detect specific pathological markers, ${ }^{50,51}$ but also to evaluate the effect of therapies ${ }^{52}$ and to investigate the role of specific signalling molecules in the onset of pathological phenotypes. ${ }^{53}$

Oxidative stress is known as a powerful factor inducing pathological processes in cells by modifying their redox state: alterations in some enzyme activities have been investigated with special attention to those occurring as a consequence of hypoxia-reoxygenation. ${ }^{54-57}$ The evidence that hypoxia and aging in the myocardial tissue are controlled by p53 and telomerase activity $^{57}$ confirms that molecular events modifying nuclear structure and function often play a pivotal role in pathogenesis; this is apparently confirmed by several articles in which nuclear histochemistry has been profitably used to elucidate basic mechanisms leading to the patho- logical cell phenotype. . $3-27,58-60^{2}$

Finally, a new frontier of histochemistry seems to open in the field of tissue engineering, ${ }^{61,62}$ transplantation, ${ }^{63}$ and adipocytederived tissue reconstruction. ${ }^{64,65}$

\section{Conclusions}

The application of refined techniques for investigating gene expression in situ has greatly increased the diagnostic/prognostic potential of histochemistry, while the progress in light microscopy technology and in the methods for imaging molecules in vivo has provided a valuable tools for elucidating the molecular events and the basic mechanisms leading to a pathological condition.

In particular, nowadays two techniques are being utilized on pathological material, and they start from opposite directions: the already established super-resolution techniques such as STED (Stimulated Emission Depletion) microscopy ${ }^{66}$ are now being tested on cells and subcellular structures, for purely diagnostic purposes, while MALDI (Matrix Assisted Laser Desorption/Ionization) analysis ${ }^{67}$ only needs to approach a sufficiently high resolution to be profitably used at the cellular level. Consistently, in his closing statement to the $53^{\text {rd }}$ Symposium of the Society for Histochemistry, the President of the Society, Prof. Marco Biggiogera underlined that MALDI analyses and imaging promise to be extraordinarily analytical techniques and a new powerful tool for pathologists.

It might therefore be expected that, even in the future, histochemistry will keep a leading position in clinical pathology, and the histochemical journals will continue to be a widely attended forum for both clinicians and basic scientists in the biomedical field.

\section{References}

1. Abu-Asab MS, Chaouchi M, Alesci S, Galli S, Laassri M, Cheema AK, et al. Biomarkers in the age of omics: time for a systems biology approach. OMICS 2011;15:105-12

2. Vollmer E, Goldman T. Pathology at the edge of interdisciplinarity: a histocrical epitome. Rom J Morphol Embryol 52(Suppl.1):2123-30.

3. Pellicciari C. Histochemistry through the years, browsing a long-established journal: novelties in traditional subjects. Eur $\mathbf{J}$ Histochem. 2010;54:e51.

4. Proceedings of the 33rd National Congress of the Italian Society of Histochemistry,
June 8-10, 2009, Rome, Italy. Eur J Histochem 2009;53(Suppl.1):1-56.

5. Kalnina Z, Silina K, Bruvere R, Gabruseva N, Stengrevics A, Barnikol-Watanabe S, et al. Molecular characterisation and expression analysis of SEREX-defined antigen NUCB2 in gastric epithelium, gastritis and gastric cancer. Eur J Histochem 2009;53:718.

6. Pilloni L, Bianco P, Manieli C, Senes G, Coni P, Atzori L, et al. Immunoreactivity for alpha-smooth muscle actin characterizes a potentially aggressive subgroup of little basal cell carcinomas. Eur J Histochem 2009;53:113-6.

7. Ruggeri RM, Ferraù F, Campennì $A$, Simone A, Barresi V, Giuffrè G, et al. Immunohistochemical localization and functional characterization of somatostatin receptor subtypes in a corticotropin releasing hormone-secreting adrenal phaeochromocytoma: review of the literature and report of a case. Eur J Histochem 2009;53:1-6.

8. Gonelli A, Milani D, Rimondi E, Voltan R, Grill V, Celeghini C. Activation of PKCepsilon counteracts maturation and apoptosis of HL-60 myeloid leukemic cells in response to TNF family members. Eur J Histochem 2009;53:177-82.

9. Cvejic D, Selemetjev S, Savin S, Paunovic I, Tatic S. Changes in the balance between proliferation and apoptosis during the progression of malignancy in thyroid tumours. Eur J Histochem 2009;53:65-71.

10. Fanni D, Nemolato S, Ganga R, Senes G, Gerosa C, Van Eyken P, et al. Cytokeratin 20-positive hepatocellular carcinoma. Eur J Histochem 2009;53:269-73.

11. Pilloni L, Manieli C, Senes G, Ribuffo D, Faa G. Merkel cell carcinoma with an unusual immunohistochemical profile. Eur J Histochem 2009;53:275-8.

12. Artico M, Bronzetti E, Alicino V, Ionta B, Bosco S, Grande C, et al. Human gallbladder carcinoma: Role of neurotrophins, MIB-1, CD34 and CA15-3. Eur J Histochem 2010;54:e10.

13. Nemolato S, Cabras T, Fanari MU, Cau F, Fraschini M, Manconi B, et al. Thymosin beta 4 expression in normal skin, colon mucosa and in tumor infiltrating mast cells. Eur J Histochem 2010;54:e3.

14. Nowak D, Mazur AJ, Popow-Woźniak A, Radwańska A, Mannherz HG, MalickaBłaszkiewicz M. Subcellular distribution and expression of cofilin and ezrin in human colon adenocarcinoma cell lines with different metastatic potential. Eur J Histochem 2010;54:e14.

15. Ruggeri RM, Vitarelli E, Barresi G, Trimarchi F, Benvenga S, Trovato M. The tyrosine kinase receptor c-met, its cognate 
ligand HGF and the tyrosine kinase receptor trasducers STAT3, PI3K and RHO in thyroid nodules associated with Hashimoto's thyroiditis: an immunohistochemical characterization. Eur J Histochem 2010;54:e24.

16. Artico M, Bronzetti E, Ionta B, Bruno M, Greco A, Ruoppolo G, et al. Reinke's edema: investigations on the role of MIB-1 and hepatocyte growth factor. Eur $\mathrm{J}$ Histochem 2010;54:e30.

17. Perrone G, Morini S, Santini D, Rabitti C, Vincenzi B, Alloni R, et al. Human equilibrative nucleoside transporter 1 and carcinoma of the ampulla of Vater: expression differences in tumour histotypes. Eur J Histochem 2010;54:e38.

18. Salemi M, Calogero AE, Zaccarello G, Castiglione R, Cosentino A, Campagna C, et al. Expression of SPANX proteins in normal prostatic tissue and in prostate cancer. Eur J Histochem 2010;54:e41.

19. Bujas T, Marusic Z, Peric Balja M, Mijic A, Kruslin B, Tomas D. MAGE-A3/4 and NYES0-1 antigens expression in metastatic esophageal squamous cell carcinoma. Eur J Histochem 2011;55:e7.

20. Protrka Z, Arsenijevic S, Dimitrijevic A, Mitrovic S, Stankovic V, Milosavljevic M, et al. Co-overexpression of bcl-2 and c-myc in uterine cervix carcinomas and premalignant lesions. Eur J Histochem 2011;55:e8.

21. Shen Z, Ren Y, Ye D, Guo J, Kang C, Ding H. Significance and relationship between DJ-1 gene and survivin gene expression in laryngeal carcinoma. Eur $\mathrm{J}$ Histochem 2011;55:e9.

22. Pilloni L, Bianco P, Difelice E, Cabras S, Castellanos ME, Atzori L, et al. The usefulness of c-Kit in the immunohistochemical assessment of melanocytic lesions. Eur J Histochem 2011;55:e20.

23. Tsirakis G, Pappa CA, Kaparou M, Katsomitrou V, Hatzivasili A, Alegakis T, et al. Assessment of proliferating cell nuclear antigen and its relationship with proinflammatory cytokines and parameters of disease activity in multiple myeloma patients. Eur J Histochem 2011;55:e21.

24. Piras F, Ionta MT, Lai S, Perra MT, Atzori F, Minerba L, et al. Nestin expression associates with poor prognosis and triple negative phenotype in locally advanced (T4) breast cancer. Eur J Histochem 2011; 55:e39.

25. Malatesta M, Meola G. Structural and functional alterations of the cell nucleus in skeletal muscle wasting: the evidence in situ. Eur J Histochem 2010;54:e44.

26. Perdoni F, Malatesta M, Cardani R, Giagnacovo M, Mancinelli E, Meola G, et al. RNA/MBNL1-containing foci in myoblast nuclei from patients affected by myotonic dystrophy type 2: an immunocytochemical study. Eur J Histochem 2009; 53:151-8

27. Malatesta M, Perdoni F, Muller S, Zancanaro C, Pellicciari C. Nuclei of aged myofibres undergo structural and functional changes suggesting impairment in RNA processing. Eur J Histochem 2009;53: 97-106.

28. Malatesta M, Giagnacovo M, Renna LV, Cardani R, Meola G, Pellicciari C. Cultured myoblasts from patients affected by myotonic dystrophy type 2 exhibit senescence-related features: ultrastructural evidence. Eur J Histochem 2011;55:e26.

29. Casadei L, Vallorani L, Gioacchini AM, Guescini M, Burattini S, D'Emilio A, et al. Proteomics-based investigation in $\mathrm{C} 2 \mathrm{C} 12$ myoblast differentiation. Eur J Histochem 2009;53:261-8.

30. Cardani R, Mancinelli E, Giagnacovo M, Sansone V, Meola G. Ribonuclear inclusions as biomarker of myotonic dystrophy type 2, even in improperly frozen or defrozen skeletal muscle biopsies. Eur J Histochem 2009;53:107-11.

31. Karen P, Števanec M, Smerdu V, Cvetko E, Kubínová L, Eržen I. Software for muscle fibre type classification and analysis. Eur J Histochem 2009;53:87-95.

32. Giagnacovo M, Cardani R, Meola G, Pellicciari C, Malatesta M. Routinely frozen biopsies of human skeletal muscle are suitable for morphological and immunocytochemical analyses at transmission electron microscopy. Eur J Histochem 2010;54:e31.

33. Xue J, Chen H, Diao L, Chen X, Xia D. Expression of caveolin-1 in tongue squamous cell carcinoma by quantum dots. Eur J Histochem 2010;54:e20.

34. Petr T, Smíd V, Smídová J, Hůlková H, Jirkovská M, Elleder M, et al. Histochemical detection of GM1 ganglioside using cholera toxin-B subunit. Evaluation of critical factors optimal for in situ detection with special emphasis to acetone pre-extraction. Eur J Histochem 2010;54:e23.

35. Relucenti M, Heyn R, Petruzziello L, Pugliese G, Taurino M, Familiari G. Detecting microcalcifications in atherosclerotic plaques by a simple trichromic staining method for epoxy embedded carotid endarterectomies. Eur J Histo chem 2010;54:e33.

36. Galvão MJ, Santos A, Ribeiro MD, Ferreira A, Nolasco F. Optimization of the tartrateresistant acid phosphatase detection by histochemical method. Eur J Histochem 2011;55:e1.

37. Battistelli S, Citterio B, Baldelli B, Parlani C, Malatesta M. Histochemical and mor- pho-metrical study of mouse intestine epithelium after a long term diet containing genetically modified soybean. Eur J Histochem. 2010;54:e36.

38. Magi GE, Lopez-Romalde S, Magariños B, Lamas J, Toranzo AE, Romalde JL. Experimental Pseudomonas anguilliseptica infection in turbot Psetta maxima (L.): a histopathological and immunohistochemical study. Eur J Histochem 2009; 53:73-9.

39. Kovšca Janjatović A, Lacković G, Bozić F, Spoljarić D, Popović M, Valpotić H, et al. Histomorphometric characteristics of immune cells in small intestine of pigs perorally immunized with vaccine candidate F18ac+ nonenterotoxigenic E. coli strain. Eur J Histochem 2009;53:189-98.

40. Kovšca Janjatović A, Lacković G, Bozić F, Kezić D, Popović M, Valpotić $H$, et al. Histomorphometric evaluation of intestinal cellular immune responses in pigs immunized with live oral F4ac+ nonenterotoxigenic E. coli vaccine against postweaning colibacillosis. Eur J Histochem 2010;54:e4.

41. Dorko F, Danko J, Flešárová S, Boroš E, Sobeková A. Effect of pesticide bendiocarbamate on distribution of acetylcholineand butyrylcholine-positive nerves in rabbit's thymus. Eur J Histochem 2011;55:e37.

42. Costa CA, De Brito KN, Gomes MA, Caliari MV. Histopathological and immunohistochemical study of the hepatic lesions experimentally induced by Entamoeba dispar. Eur J Histochem 2010;54:e39.

43. Ferrandino I, Favorito R, Grimaldi MC. Cadmium induces changes on ACTH and PRL cells in Podarcis sicula lizard pituitary gland. Eur J Histochem 2010;54:e45.

44. Ruggeri A, Orsini G, Mazzoni A, Nato F, Papa V, Piccirilli M, et al. Immunohistochemical and biochemical assay of versican in human sound predentine/dentine matrix. Eur J Histochem 2009;53:125-33.

45. Kiga N, Tojyo I, Matsumoto T, Hiraishi Y, Shinohara Y, Makino S, et al. Expression of lumican and fibromodulin following interleukin-1 beta stimulation of disc cells of the human temporomandibular joint. Eur J Histochem 2011;55:e11.

46. Kiga N, Tojyo I, Matsumoto T, Hiraishi Y, Shinohara Y, Fujita S. Expression of lumican in the articular disc of the human temporomandibular joint. Eur J Histochem 2010;54:e34.

47. Loreto C, Almeida LE, Migliore MR, Caltabiano M, Leonardi R. TRAIL, DR5 and caspase 3-dependent apoptosis in vessels of diseased human temporomandibular joint disc. An immunohistochemical study. Eur J Histochem 2010;54:e40.

48. Matsumoto T, Inayama M, Tojyo I, Kiga N, 
Fujita S. Expression of hyaluronan synthase 3 in deformed human temporomandibular joint discs: in vivo and in vitro studies. Eur J Histochem 2010;54:e50.

49. de Moraes LOC, Lodi FR, Gomes TS, Oshima CTF, Marques SR, Lancellotti CLP, et al. Immunohistochemical expression of types I and III collagen antibodies in the temporomandibular joint disc of human foetuses. Eur J Histochem 2011;55:e24.

50. Song R, Xu W, Chen Y, Li Z, Zeng Y, Fu Y. The expression of Sirtuins 1 and 4 in peripheral blood leukocytes from patients with type 2 diabetes. Eur J Histochem 2011;55:e10.

51. Sharma P, Kar R, Dutta S, Pati HP, Saxena R. Niemann-Pick disease, type B with TRAP-positive storage cells and secondary sea blue histiocytosis. Eur J Histochem 2009;53:183-6.

52. Tomasello G, Sciumé C, Rappa F, Rodolico V, Zerilli M, Martorana A, et al. Hsp10, Hsp70, and Hsp90 immunohistochemical levels change in ulcerative colitis after therapy. Eur J Histochem 2011;55:e38.

53. Markelic M, Velickovic K, Golic I, Otasevic V, Stancic A, Jankovic A, et al. Endothelial cell apoptosis in brown adipose tissue of rats induced by hyperinsulinaemia: the possible role of TNF- $\alpha$. Eur J Histochem 2011;55:e34

54. Lepore G, Gadau S, Mura A, Zedda M, Farina V. Aromatase immunoreactivity in fetal ovine neuronal cell cultures exposed to oxidative injury. Eur J Histochem 2009;53:233-8.

55. Rus A, Del Moral ML, Molina F, Peinado MA. Upregulation of cardiac NO/NOS system during short-term hypoxia and the subsequent reoxygenation period. Eur J Histochem 2011;55:e17.

56. Bolekova A, Spakovska T, Kluchova D, Toth $\mathrm{S}$, Vesela J. NADPH-diaphorase expression in the rat jejunum after intestinal ischemia/reperfusion. Eur J Histochem 2011;55:e23.

57. Cataldi A, Zara S, Rapino M, Zingariello $M$ di Giacomo V, Antonucci A. p53 and telomerase control rat myocardial tissue response to hypoxia and ageing. Eur $\mathrm{J}$ Histochem 2009;53:209-16.

58. Dominici S, Fiori V, Magnani M, Schena E, Capanni C, Camozzi D, et al. Different prelamin A forms accumulate in human fibroblasts: a study in experimental models and progeria. Eur $\mathrm{J}$ Histochem 2009;53:43-52.

59. Cortés-Gutiérrez EI, Dávila-Rodríguez MI, Fernández JL, López-Fernández C, Gosálvez J. Koilocytes are enriched for alkaline-labile sites. Eur J Histochem 2010;54:e32.

60. Cenni V, Capanni C, Columbaro M, Ortolani M, D'Apice MR, Novelli G, et al. Autophagic degradation of farnesylated prelamin A as a therapeutic approach to lamin-linked progeria. Eur J Histochem 2011;55:e36.
61. Corallini F, Gonelli A, D’Aurizio F, Di Iasio MG, Vaccarezza M. Mesenchymal stem cells-derived vascular smooth muscle cells release abundant levels of osteoprotegerin. Eur J Histochem 2009;53:19-24.

62. Musumeci G, Loreto C, Carnazza ML, Coppolino F, Cardile V, Leonardi R. Lubricin is expressed in chondrocytes derived from osteoarthritic cartilage encapsulated in poly(ethylene glycol) diacrylate scaffold. Eur J Histochem 2011; 55:e31.

63. Boncompagni E, Gini E, Ferrigno A, Milanesi G, Gringeri E, Barni S, et al. Decreased apoptosis in fatty livers submitted to subnormothermic machine-perfusion respect to cold storage. Eur J Histochem 2011;55:e40.

64. Sbarbati A, Accorsi D, Benati D, Marchetti L, Orsini G, Rigotti G, et al. Subcutaneous adipose tissue classification. Eur J Histochem 2010;54:e48.

65. Panettiere P, Accorsi D, Marchetti L, Minicozzi AM, Orsini G, Bernardi P, et al. The trochanteric fat pad. Eur J Histochem 2011;55:e16.

66. Leung B0, Chou KC. Review of super-resolution fluorescence microscopy for biology. Appl Spectrosc 2011;65:967-80.

67. Balluff B, Schoene C, Hoefler H, Walch A. MALDI imaging mass spectrometry for direct tissue analysis: technological advancements and recent applications. Histochem Cell Biol 2011;136:227-44. 